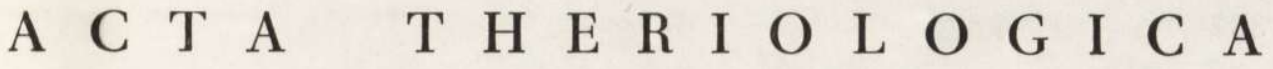 \\ VOL. 19, 26: $381-401$. \\ BIAEOWIEŻA \\ November, 1974
}

Anna FEDYK

\section{Gross Body Composition in Postnatal Development of the Bank Vole. I. Growth Under Laboratory Conditions *}

\author{
[With 5 Tables \& 6 Figs.]
}

\begin{abstract}
Gross body composition was studied in 465 captive bank voles during postnatal development (from $1-180$ days of life). It was shown that voles from small litters ( $1-3$ young) do not differ from individuals from large litters (4-6 young) either as to degree of adiposis or the average rate of accumulation of the fat-free components of the body mass $(F F B)$. The animals reached chemical maturity at the age of $55-60$ days. The level of $F F B$ composition at the stage of chemical maturity is not a species-specific feature and only characterizes local populations. During the first 6 months of development the calorific value of a unit by weight of the protein and fat in bank voles is constant, being respectively 4.583 and $9.240 \mathrm{cal} / \mathrm{g}$.
\end{abstract}

\section{INTRODUCTION}

The large number of studies of Clethrionomys glareolus $(\mathrm{S} \mathrm{ch} \mathrm{r} \mathrm{e} \mathrm{be} \mathrm{r,}$ 1780 ), one of the dominant rodents in forest ecosystems in Europe, have contributed to what is known of the features of development and growth of this species in captivity ( $\mathrm{Sviridenko,} \mathrm{1959;} \mathrm{Petrov} \mathrm{\&} \mathrm{Aira-}$ pe t'j a n s, 1961; M a z à k, 1962; D r o żd ż, 1965) and under natural conditions (P e a r s o n, 1962; N e w s o n, 1963; B e r g s t e d t, 1965; K ubik, 1965; Bujalska \& Gliwicz, 1968; Cla ude, 1970; Crawle y, 1970; $\mathrm{Z}$ e jda, 1971; K a ikusal o, 1972). These data, however, relate to the biology of the species or to morphological parameters. An exception to this is the study by S a w i k a-Ka pusta (1974) on the quantitative relations between the main body components in bank voles during the process of growth.

Growth is an increase in the mass of the organism, consisting of the growth of tissues of which it is made, and should therefore be considered

*) Praca została zrealizowana w ramach problemu węzłowego 09.1.7., koordynowanego przez Instytut Ekologii PAN. 
as the growth of gross body components: water, protein and minerals. Accumulation of fat by the animal, which causes an increase in body mass, is primarily the process of accumulation of energy reserve components.

The purpose of the present study is to examine the rate of growth and accumulation of fat in individuals of $C$. glareolus, reared under laboratory conditions for many generations, and the relation between this rate and the size of the litter in which the animal was born and reared.

\section{MATERIAL AND METHODS}

Bank voles born in captivity in the laboratories of the Mammals Research Institute at Białowieża (8-12 generations) were used for the studies. The pairs of parent animals were kept with their progeny for 21 days, then the young were removed from their parents and each litter kept separately. The animals were fed on a mixture of oats, beet, carrot and grasses during the growing season, and had constant access to drinking water. Only natural lighting was used.

The animals were examined at the age of $1,3,6,9,12,14,16,19,22,24,27$, and 30 days, then at five-day intervals from the 35 th to 60 days, every ten days at the age of 70 to 90 days and monthly intervals up to the 180th day of life.

Analyses were made for water, protein, minerals (ash) and fat content in 465 voles born over the course of a whole year. In addition the calorific values of $1 \mathrm{~g}$ each of protein and fat were determined.

The animals for analysis were killed with ether, weighed, their sex determined, after which the alimentary tract was removed and the carcass weighed again. The eviscerated body was dried to constant weight either in a vacuum dryer at a temperature of $70^{\circ} \mathrm{C}$ or in an electric dryer at $105^{\circ} \mathrm{C}$. Water content was calculated from the difference in weight of the carcass before and after drying, assuming that water is the only volatile substance in the organism. The dried material was pounded in a mortar and the its ash, protein and fat content determined. Two or three samples were taken from each animal for the various determinations, the only exception being the 3 first age groups, for which single determinations were made.

In order to determine mineral content, samples varying from 0.1 to $0.4 \mathrm{~g}$ were burnt to constant weight in a muffle furnace at temperature of $750^{\circ} \mathrm{C}$. The average amount of ash contained in two samples was converted to ash contained in the whole dry mass of the animal. The fat content of samples from $0.1-0.3 \mathrm{~g}$ in size was determined by Puazunov's method ( $\mathrm{Kra}$ u $\mathrm{z}$ et al., 1966), using diethyl ether for extraction. Protein content was determined by Kjeldahl's method, taking about $0.02 \mathrm{~g}$ of dry mass for mineralization. The mean protein content was calculated from three parallel samples.

In order to eliminate error in calculating the averaged amounts of protein, ash and fat, standard analyses were made to definite the dispersion of the different methods. For this purpose the remains of the dry material left after analysing 10 animals 60 days old were treated as a standard test. After the material had been thoroughly mixed 30 analyses were made on it for protein, ash and fat content (Table 1). In cases in which the results obtained from one animal exceeded the difference, expressed as a percentage, between the maximum value obtained under standard conditions the measurement was repeated. 
During the series of analyses it was found that the amount of protein as determined by Kjeldahl's method differed very little from the amount of protein obtained by deducting the amount of ash and fat found in it from the dry mass of the animal (cf. F e d y k \& $\mathrm{Malzahn}$, in prep.). When converted to the average initial weight of the animal the difference between the amount of protein determined by Kjeldahl's method and that estimated by deducting ash and fat is $0.106 \%$, whereas the error caused by the use of Kjeldahl's method under these conditions may form $0.365 \%$ of the initial weight. Protein was therefore determined by Kjeldahl's method only in animals up to 60 days old - i.e. up to the time of stabilization of the protein content as a percentage of the fat-free body mass $(F F B)$. In the other animals the protein content was estimated by deducting from the dry mass the amounts of fat and ash found.

In order to define the relation between body weight and fat content the straight line regression equation was used. The straight line regression equation for a pair of characters (e.g., FFB - protein) has so far been used for analysis of the quantitative relations between the $F F B$ and its main components but, as shown by initial calculations, there is also a high degree of reciprocal correlation between the amounts of protein, ash and water in the $F F B$. For this reason use was made of the multiple regression equation ( $\mathrm{E} l \mathrm{a} \mathrm{ndt}$, 1964). which allows one to establish the

Table 1

Protein, minerals (ash) and fat contents under standard analysis conditions.

\begin{tabular}{lrrr}
\hline $\begin{array}{c}\text { Compo- } \\
\text { nent }\end{array}$ & $\begin{array}{r}\text { Mean } \underset{\mathrm{g}}{ \pm} \text { S.D. } \\
\text { Mange of }\end{array}$ & $\begin{array}{c}\text { Range } \\
\text { variability } \\
\text { Min.-Max. }\end{array}$ & $\%$ \\
\hline $\begin{array}{l}\text { Protein } \\
\text { Ash }\end{array}$ & $2.2717 \pm .0065$ & $2.2590-2.3092$ & 2.22 \\
Fat & $.4243 \pm .0045$ & $.4158-.4316$ & 3.80 \\
& $3.2899 \pm .0012$ & $3.2727-3.3035$ & .94 \\
\hline
\end{tabular}

relationship between one character and several of its components simulaneously; in this case the quantitative relationship between the reciprocally conditional effect of protein, water and minerals on the rate of $F F B$ increase.

The rate of FFB growth, as described by multiple regression equations, does not, however, fully reflect the essence of the growth phenomenon, only giving the average values for the given period of growth. As the rate of growth differs during individual development, four stages of growth were distinguished: I. $1-19$, II. 22-40, III. $45-60$ and IV. $70-180$ days of life. The first of these stages corresponds to the period which the young spend with the mother, the two following were determined on the basis of the age at which chemical maturity is attained by this species under conditions close to natural ones ( $\mathrm{Fedyk}, 1974 \mathrm{a}$ ), and the fourth stage covers the remaining period of development.

Equations of straight and multiple regressions for the growth stages and for the whole study period were tested in the following way: (1) testing the significance of the equations ( $t$-test), (2) comparing appropriate pairs of equations by the covariance analysis method ( $F$-Snedecor's test) for coefficient of regression $b$ and 
coefficient $a$ (Elandt, 1958). When it was found that the two equations of regression compared were uniform (appearing on the diagram as parrellel straight lines running at a uniform height) they were replaced by a joint equation.

In order to make allowance for the possible effect of a different start in life of the voles or their later development separate statistical analysis was made of data obtained from animals born and reared in small ( $1-3$ individuals) and large litters (4-6 individuals), irrespective of sex, as the parameters examined are not correlated with sex.

\section{RESULTS}

\section{Growth of Individuals of Bank Voles Born and Reared in Small Litters}

During the period from the 1st to the 180th day of life $F F B$ in voles increases seven times over, its most intensive increase occuring during the first month of life (5.5 times) (Table 2). The average rate of growth is then $0.334 \mathrm{~g} /$ day, whereas the average rate of growth for the period covering the first 6 months of life is $0.068 \mathrm{~g} /$ day. Thus after a period of intensive growth, which in fact takes place during the last ten days of the first month of life, there is a slow increase at an average of 0.016 g/day. The sevenfold increase in $F F B$ during a period of six months is made up by a 5.7 -fold increas in water content, an over 16 -fold increase in protein and an over 20 -fold increase in mineral content, the rate at which these components are accumulated differeing, as can be clearly seen from the equations of multiple regression for the various stages of growth (Table 3). Water content increases fastest in period III (from 45-60 day of life) and most slowly in period I, that is the reverse of protein mass, which increases over 10 times more rapidly in develpment stage I than in stage III. Protein, however, increases most quickly in period II. Increase in mineral content is most rapid in period I, slightly slower in II and slowest in III, to rise again in period IV, but to a lesser degree than in period II.

It is primarily water which exerts the greatest influence on $F F B$ increase over the first 6 months, then the increase in protein and minerals. Thus after taking into consideration the reciprocally correlated increase in basic components, their influence on $F F B$ increase is seen to be different from that which is obtained from simple calculation of percentages (cf. Table 2).

It must be emphasised that the average fat-free body mass of 40-day old voles is higher than of 60 -day old individuals (difference statistically significant with $0.01<\mathrm{P}<0.05$ ). This reduction in $F F B$ in older animals in comparison with younger ones also involves a reduction by $1.02 \mathrm{~g}$ of the absolute averages for water content and to a lesser degree of protein 


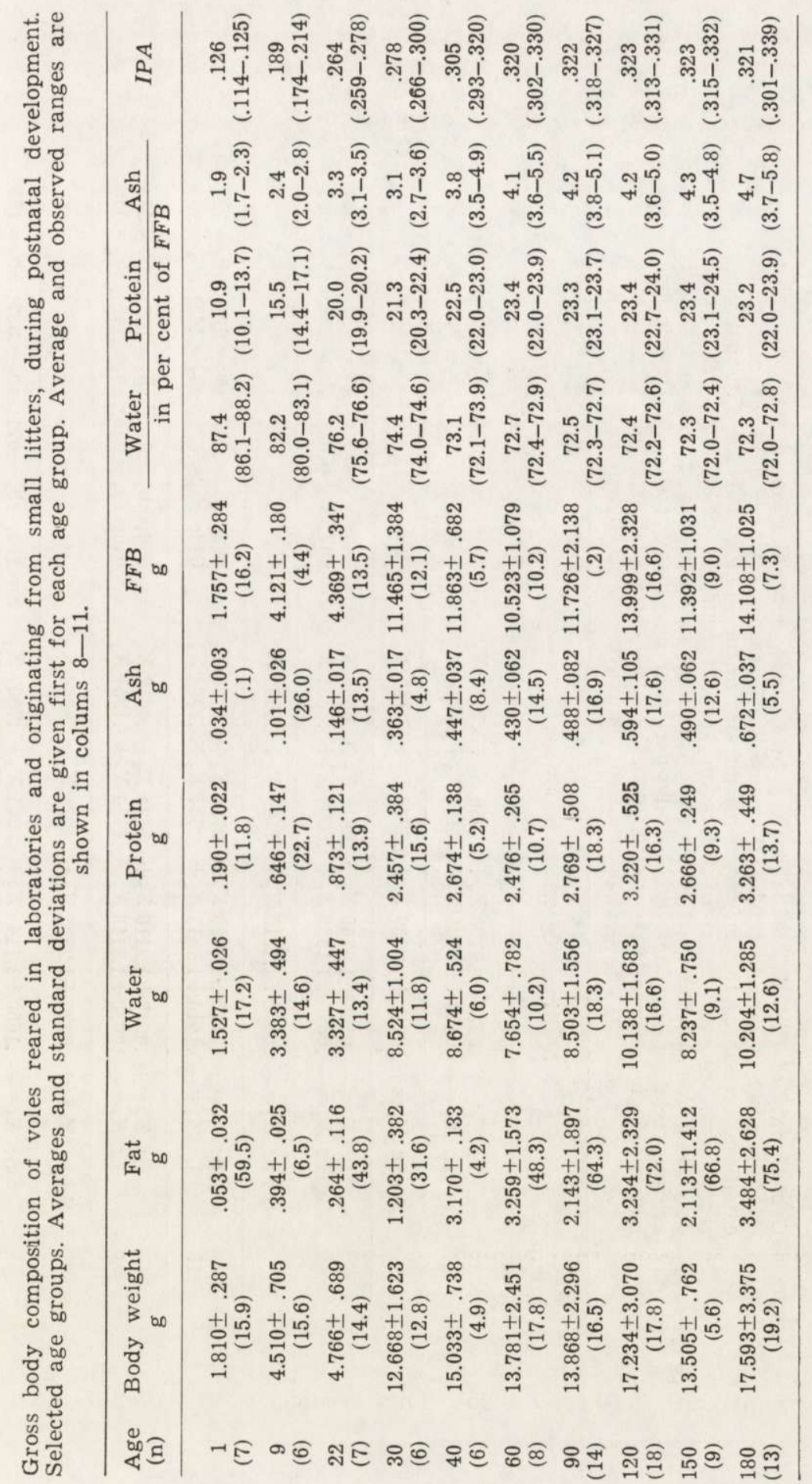




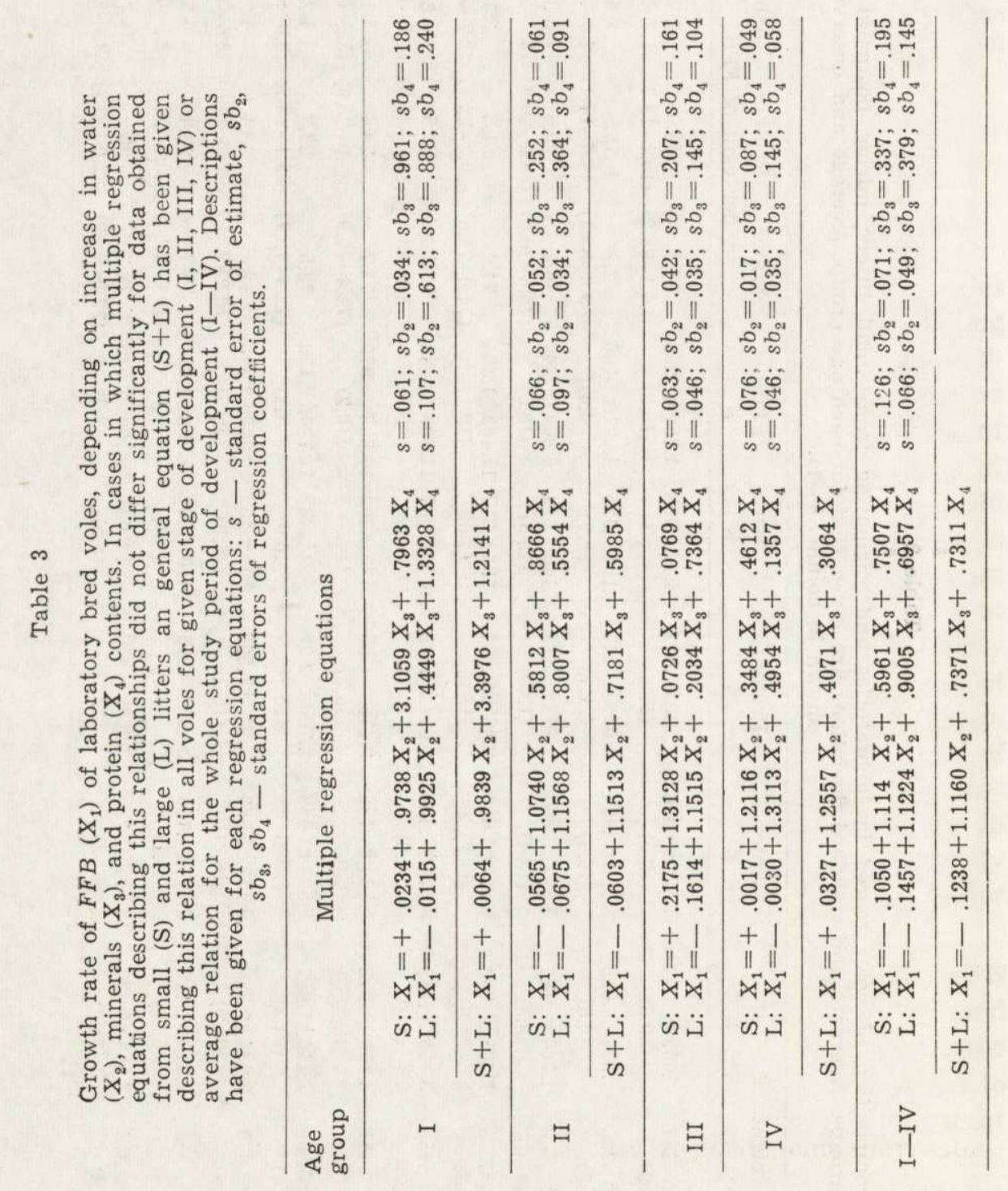


and minerals. The second reduction in $F F B$ occurs during the fifth month of life, in which $F F B$ is $2.60 \mathrm{~g}$ lower than the average value of this parameter for four month old voles (difference statistically significant) and is even $0.47 \mathrm{~g}$ lower than in 40 -day old voles (difference not statistically significant).

\section{Growth of Individuals of Bank Voles Born and Reared in Large Litters}

Table 4 contains part of the results (some of the age groups) relating to the gross body composition of animals belonging to large litters. These voles are characterized by relatively greater $F F B$ values from the time of birth to the end of the period spent with their parents, in comparison with animals reared in small litters. These differences are, however, not statistically significant until after the period of nest life which ends about the 22nd day of life. During farther development the average $F F B$ weight in voles beloging to large litters is lower than those from small litters, particularly on the 30th, 40th and 180th day of life. Average growth rate during the first 6 months of life is $0.065 \mathrm{~g} /$ day and for the first month of life is $0.289 \mathrm{~g} /$ day. The average $F F B$ weight of 150 and 180 day old voles is non-significantly lower than this parameter in 120-day old voles.

As in the case of the data obtained for small litters, the rate of FFB increase differs in each of the stages distinguished (Table 3). In period I protein exerts the greatest influence on $F F B$ increase. In periods II and III (22-60 days) the rate of $F F B$ growth decreases under the influence of protein and is slowest in period IV, in which it forms only $10 \%$ of the increase shown in period I. The rate of FFB increase due to water differs very little in the various periods, but the influence of minerals on FFB increase differs considerably - being greatest in period II, less in IV and I and least in III ( $25 \%$ as compared to I).

\section{Growth of Voles Reared in Laboratory Conditions}

During the first 6 -months of development the average growth rate in captive voles, the measure of which is FFB increase, calculated by comparing the average $F F B$ weight on the day of birth with the final average $F F B$ wt. differs in individuals from large litters in comparison with voles from small litters (respectively 0.051 and $0.069 \mathrm{~g} /$ day). These values do not, however, characterize the growth rate of the two groups of voles, since in the case of voles born in large litters the average FFB weight cn the 180th day of life is lower than the value of this parameter in animals 3, 4 and 5-months old. The average FFB value, on the other hand, in voles from small litters is the maximum value attained by this 


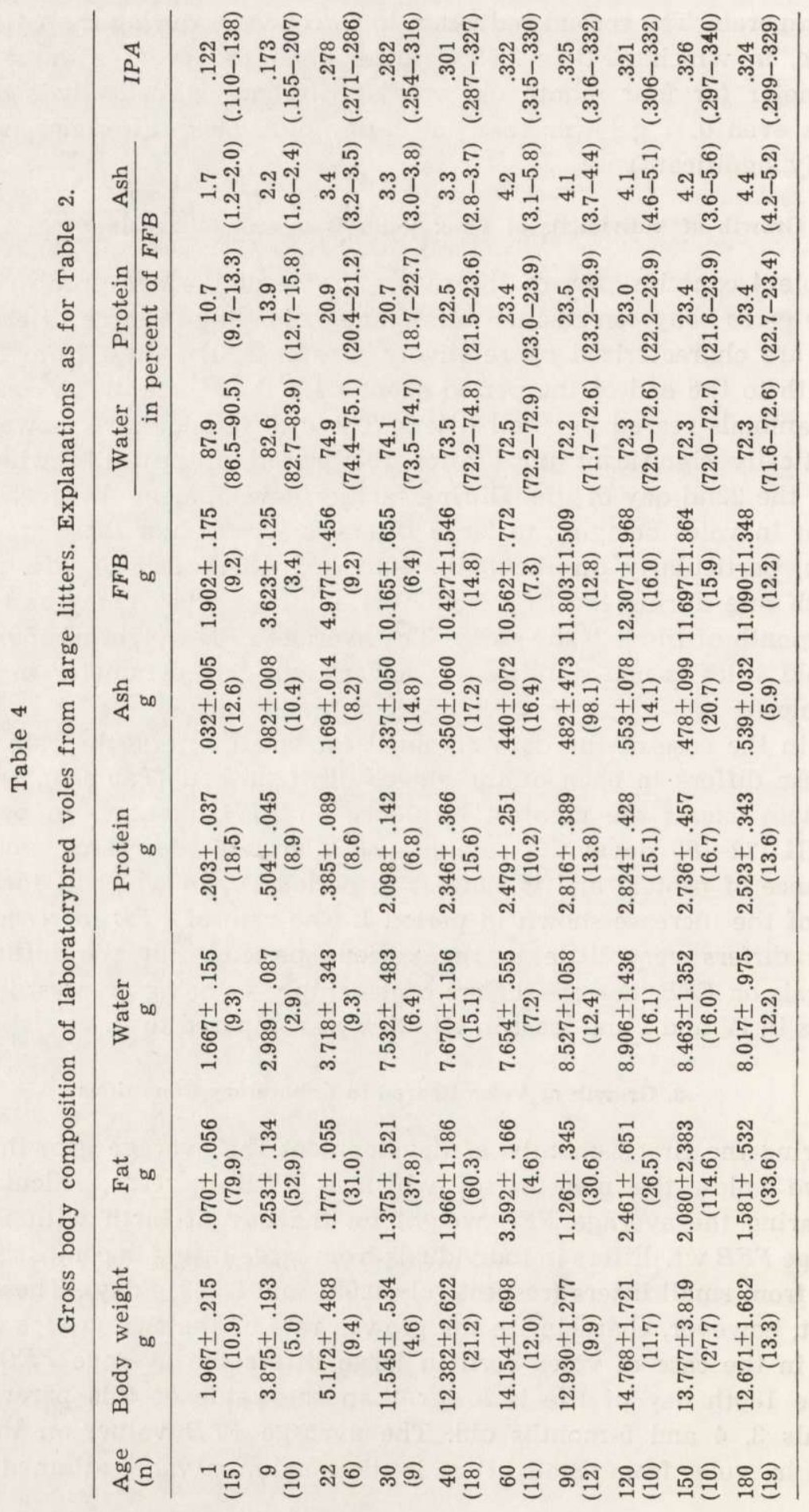


group of animals during their growth. Therefore, on account of a periodic reduction in the average $F F B$ values, comparisons of growth rate are incorrect. All comparisons of the average growth rate of basic components are burdened with a similar error, as the reduced $F F B$ values are accompanied by correspondingly lower values of its components. It is more rational to compare the growth rate of the $F F B$ as a function of its components, omitting the age factor (multiple regression equations for the whole period of development studied) or allowing for age as a superior value in relation to data obtained from analysis of a given group of animals (multiple regression equations for the various stages of development).

The average rate of $F F B$ increase for the 6 -month period of development under the influence of its three components is sufficiently

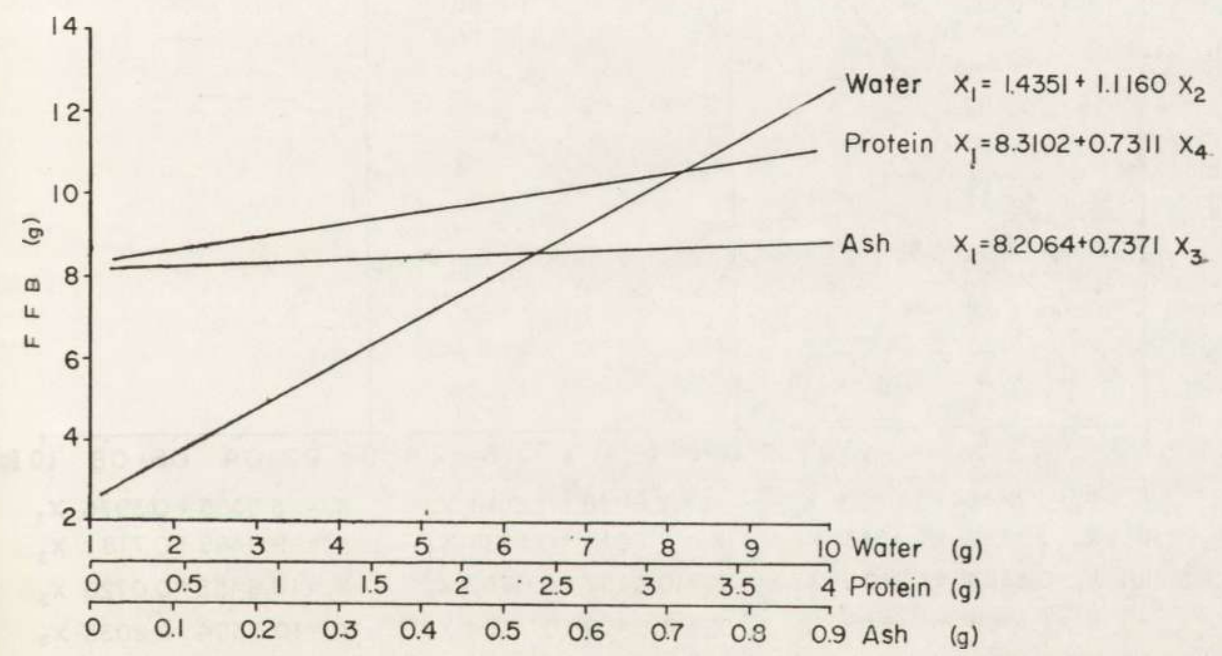

Fig. 1. Average growth rate of $F F B$ in laboratory-bred voles depending on growth rate of its various components.

similar for the two groups for them to be described by one joint equation (Table 3, Fig. 1). Water is the most important factor in the increase of $F F B$ mass. Unit increase of water corresponds to an $F F B$ increase of 1.11 units. The participation of protein in the increase of FFB mass is almost indentical to that of minerals.

A similar FFB growth rate as a function of water, protein and minerals characterizes voles born and reared in small and large litters at time intervals of less than 6 months. It is only period III, covering the time from the 45 th to 60 th day of life, which forms an exception. This enabled us to describe the rate of increase in FFB components in periods I, II, 
IV as common to all voles, whether born in large or small litters (Teble 3, Fig. 1).

During the first 19 days of life, protein influences $F F B$ increase in laboratory voles to the greatest degree (1.21 unit of $F F B /$ unit of increase in protein). During development period II between the 22nd and 40th day of life the participation of protein in $F F B$ increase is reduced to half in comparison with period I, and in period IV ( $70-180$ day of life) it forms only $25 \%$ of the participation of protein in period $I$.

Minerals were most important in FFB formation during period II ( 0.72 unit of $F F B /$ unit increase of minerals) and were the same in period I as in period IV $(0.40 \mathrm{FFB} /$ minerals $)$.

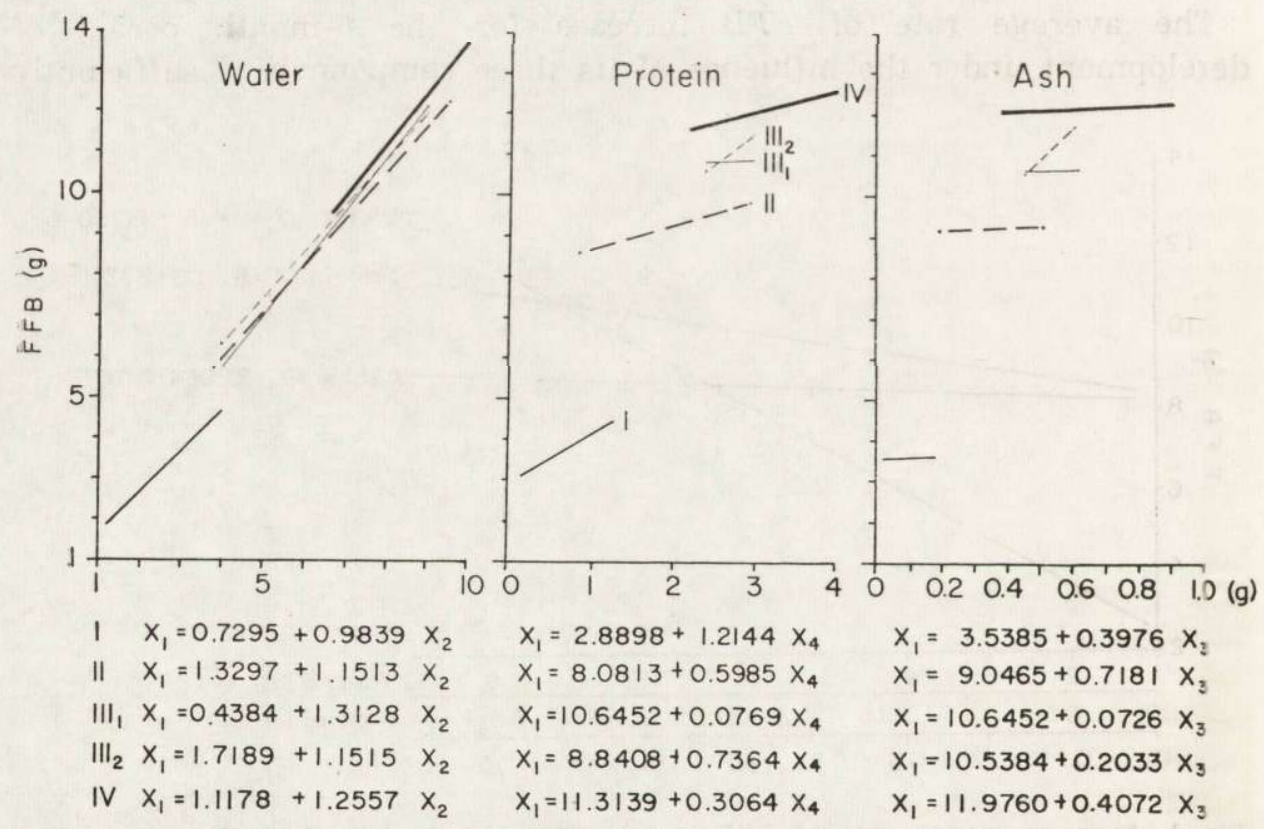

Fig. 2. Growth rate of $F F B$ depending on increse in water, protein and minerals (ash) in different periods of the development of laboratory-bred voles. The percentage of the various components in FFB growth for period III of development is statistically significant for small litters $\left(\mathrm{III}_{1}\right)$ and large litters $\left(\mathrm{III}_{2}\right)$.

It is only the effect of water on the increase in $F F B$ that is similar in all three periods (Fig. 2).

Between the 45th and 60th day of life the growth rate of the FFB due to the influence of protein is more than nine times lower in individuals from small litters than in individuals born in large litters, and in addition the rate of increment of minerals is also differentiated (Fig. 2).

As shown earlier on, the average growth rate of the FFB and the participation in this increase of the three basic components is uniform 
in all voles reared in a laboratory, and this justifies treating this group of animals as homogeneous with respect to the components examined. The growth rate of the $F F B$ in voles kept for several generations under laboratory conditions varies, the increase being rapid during the first month of life, i.e. on average from $1.85 \mathrm{~g}$ to $10.56 \mathrm{~g}$. There is a relatively slight $F F B$ increase during further development, this value attaining a maximum on the 120 th day of life $(13.40 \mathrm{~g})$ (Fig. 3). The basic compo-

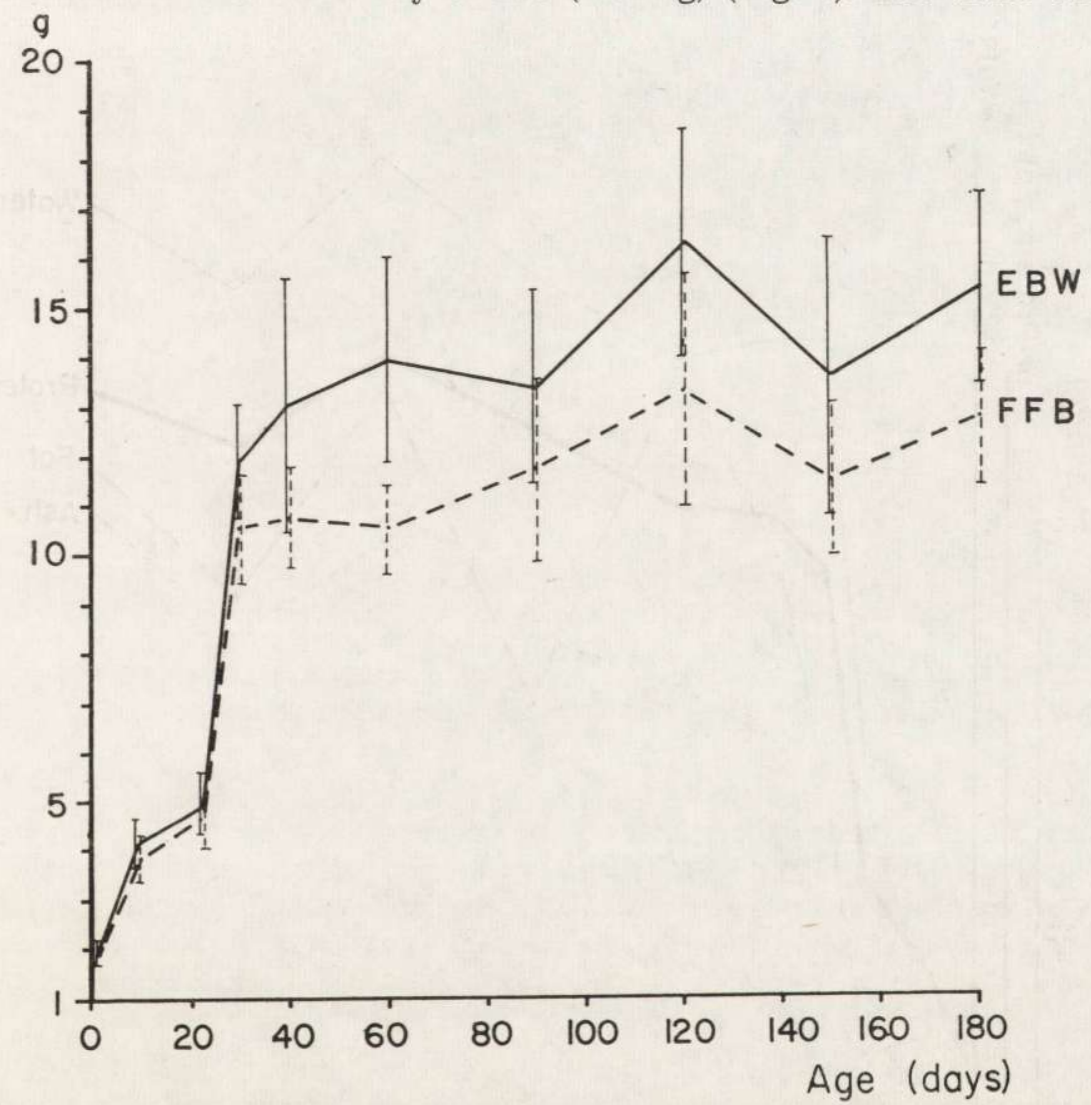

Fig. 3. Body weight $(E B M)$ and fat-free body mass $(F F B)$ during the postnatal development of laboratory-bred voles. Vertical lines indicate standard deviations from average value on a given day of life.

nents of the body are characterized by a similar rate of growth and except for minerals - also reach their maximal values in the 120 th day of life (Fig. 4).

\section{Adiposis}

It was found that eviscerated body weight is correlated with adiposis. The regression equations describing this relation are highly significant $(P<0.001)$ (Table 5). 
A characteristic feature of adiposis in the voles examined is an intensive accumulation of fat during the first 22 days of life (Table 5 and also Tables 2 and 4), less intensive during the period from the 24th-40th day of life and even less during the later stages of development. Captive voles attain a maximum accumulation of fat at the age of 60 days.

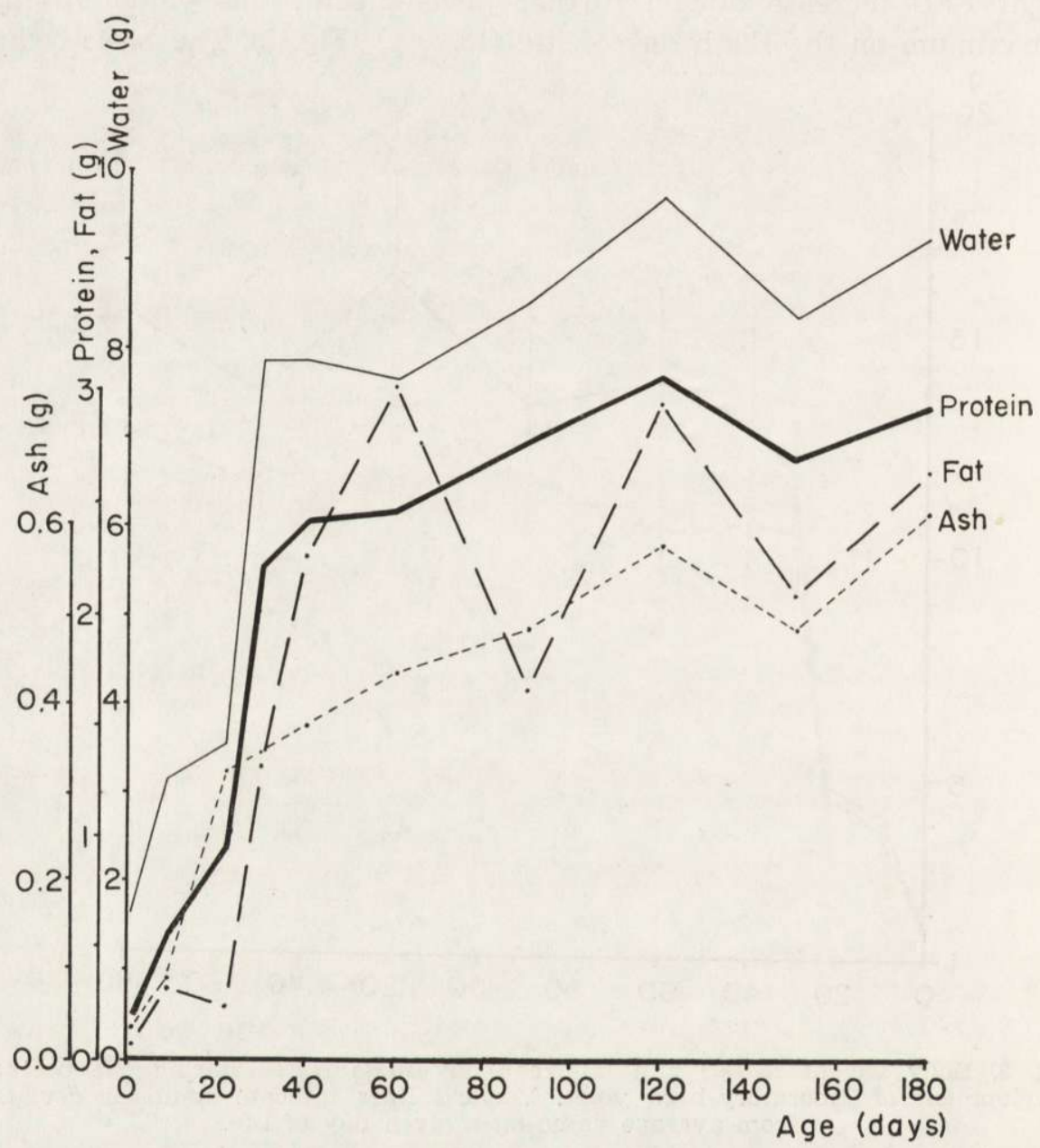

Fig. 4. Quantitative increase in $G B C$ during postnatal development of laboratory-bred voles irrespective to litter size. Thick line indicates average relationship for 6 months of development. The remaining lines relate to the various periods of development.

Voles belonging to large litters have a greater accumulation of fat on the day of birth than individuals from small litters. As development proceeds, the degree of fat accumulation in voles belonging to the two groups differs, e.g. on the 40th day of life voles from large litters are 
on an average $1.20 \mathrm{~g}$ fatter than voles from small litters. On account of the great variability in this parameter, however, (see coefficient of variation in Tables 2 and 4) all differences between these characters depending on litter size are statistically non-significant, which makes it possible to describe trends in adiposis jointly for the groups compared (see Table 5, Fig. 5).

\section{Composition in Percentages of the FFB}

Voles reared in a laboratory, irrespective of the season in which they were born and of litter size, have over $87 \%$ of water in their fat-free body on the day of birth, almost $11 \%$ of protein and about $2 \%$ of minerals (Tables 2 and 4). The percentage water content in the FFB decreases with age, reaching a constant level of about $72 \%$ at an age of $55-60$

Table 5

Relation between fat content $(X)$ and eviscerated body weight $(Y)$ in laboratory-bred voles. $n-$ numbers, $r-$ coefficient of correlation, $s_{y}-$ standard of estimate, $s b-$ standard error of regression coefficient.

\begin{tabular}{|c|c|c|c|}
\hline $\begin{array}{l}\text { Age } \\
\text { groups } \\
\text { (days) }\end{array}$ & Small litters & Large litters & $\begin{array}{l}\text { Small+Large } \\
\text { litters }\end{array}$ \\
\hline$\underset{(1-i 9)}{\mathrm{I}}$ & $\begin{array}{l}\mathrm{Y}=2.0078+6.4068 \times \mathrm{X}=39 \\
r=.887 ; s_{y}=.714 ; s b=.548\end{array}$ & $\begin{array}{c}\mathrm{Y}=2.0024+7.5778 \times \mathrm{n}=102 \\
r=.878 ; s_{y}=.758 ; s b=.413\end{array}$ & $Y=2.4790+7.2084 X$ \\
\hline$\underset{(22-40)}{\mathrm{II}}$ & $\begin{array}{c}\mathrm{Y}=5.4452+3.3550 \times \mathrm{n}=28 \\
r=.900 ; s_{y}=2.009 ; s b=.319\end{array}$ & $\begin{array}{c}\mathrm{Y}=6.6009+2.9360 \times \mathrm{X}=63 \\
r=.897 ; s_{y}=1.411 ; s b=.185\end{array}$ & $Y=6.2573+3.0839 X$ \\
\hline$\underset{(45-60)}{\text { III }}$ & $\begin{aligned} \mathrm{Y} & =10.2548+1.1424 \times \mathrm{X}=20 \\
r & =.889 ; s_{y}=.986 ; s b=.138\end{aligned}$ & $\begin{aligned} \mathrm{Y} & =9.4285+1.3621 \times \mathrm{X}=32 \\
r & =.895 ; s_{y}=.966 ; s b=.124\end{aligned}$ & $Y=9.8306+1.2568 X$ \\
\hline$\underset{(70-180)}{\operatorname{IV}}$ & $\begin{array}{c}\mathrm{Y}=11.4242+1.4435 \times \mathrm{n}=74 \\
r=.798 ; s_{y}=2.185 ; s b=.129\end{array}$ & $\begin{aligned} \mathrm{Y} & =11.4631+1.0346 \times \mathrm{X}=59 \\
r & =.716 ; s_{y}=1.156 ; s b=.150\end{aligned}$ & $Y=11.1965+1.4171 X$ \\
\hline $\begin{array}{c}\mathrm{I}-\mathrm{IV} \\
(1-180)\end{array}$ & $\begin{array}{c}\mathrm{Y}=6.5386+2.5264 \times \mathrm{X}=161 \\
r=.820 ; s_{y}=.322 ; s b=.140\end{array}$ & $\begin{array}{c}\mathrm{Y}=5.3706+2.6156 \times \mathrm{X}=256 \\
r=.803 ; s_{y}=2.780 ; s b=.125\end{array}$ & $Y=5.7621+2.7311 X$ \\
\hline
\end{tabular}

days. On the other hand, the percentages of protein and minerals in the FFB increase and also attain a constant level at the same age of the animal as in the case of water. The established protein level is about $23 \%$ and ash slightly above $4 \%$. Captive voles thus attain chemical maturity at the age of 55-60 days (Fig. 6) (See Moulto n, 1923).

B a iley, Kitts \& Wood (1960) introduced the concept of physiological age (index of physiological age) which is expressed in the quotient of protein content to water content. This index increase with the 
animal's age. The index of physiological age in the voles examined does: not depend on the time at which they were born, but only on the absolute age of the animals, and during a 6-month period comes within limits of $0.128-0.324$ in both the groups compared (cf. Tables 2 and 4).

\section{Calorific Value}

The calorific values of one gram of protein and of fat were determined, using samples of dried material from voles from 1 to 50 days old (i.e.

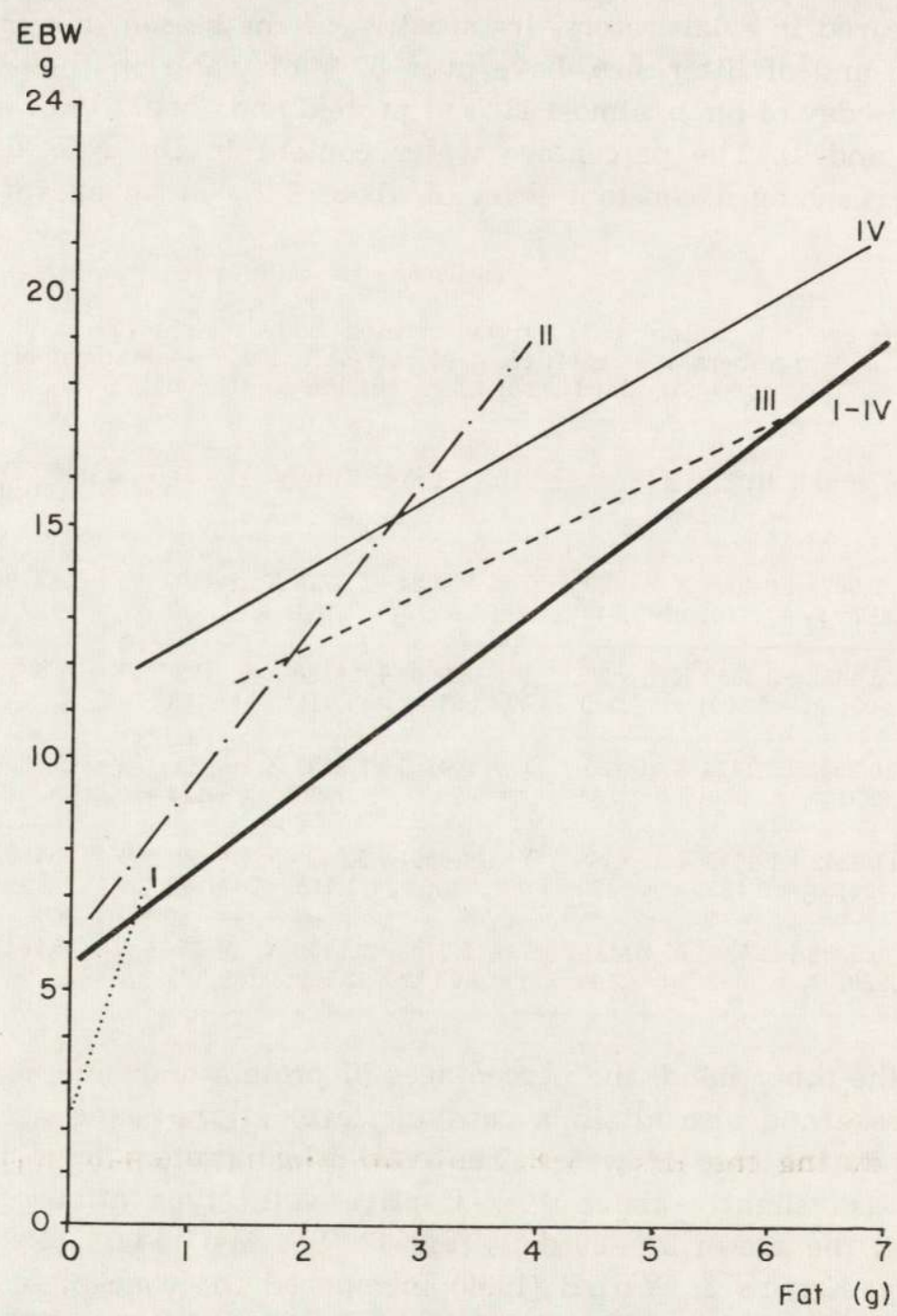

Fig. 5. Relation between body weight and fat content in laboratory-bred voles. Thick line indicates average relations for 6 months of development. The remaining lines relate to the various periods of development. 
before the animals had reached chemical maturity), and from chemically mature animals, making a total of 48 measurements. It was found that, irrespective of the voles' age, the calorific value of the protein contained in the body is $5583.48 \mathrm{cal} / \mathrm{g}$, and of fat is $9249.41 \mathrm{cal} / \mathrm{g}$.

\section{DISCUSSION}

Growth rate under optimum conditions is a parameter characteristic of a species and the term "species-specific growth rate " is frequently used (M orrison et al., 1954; Emeli a nov, 1966). Growth rate may, however, vary within narrow limits depending on the size of the litter in which the animals were born and grew up. P e a r s o n (1962) showed

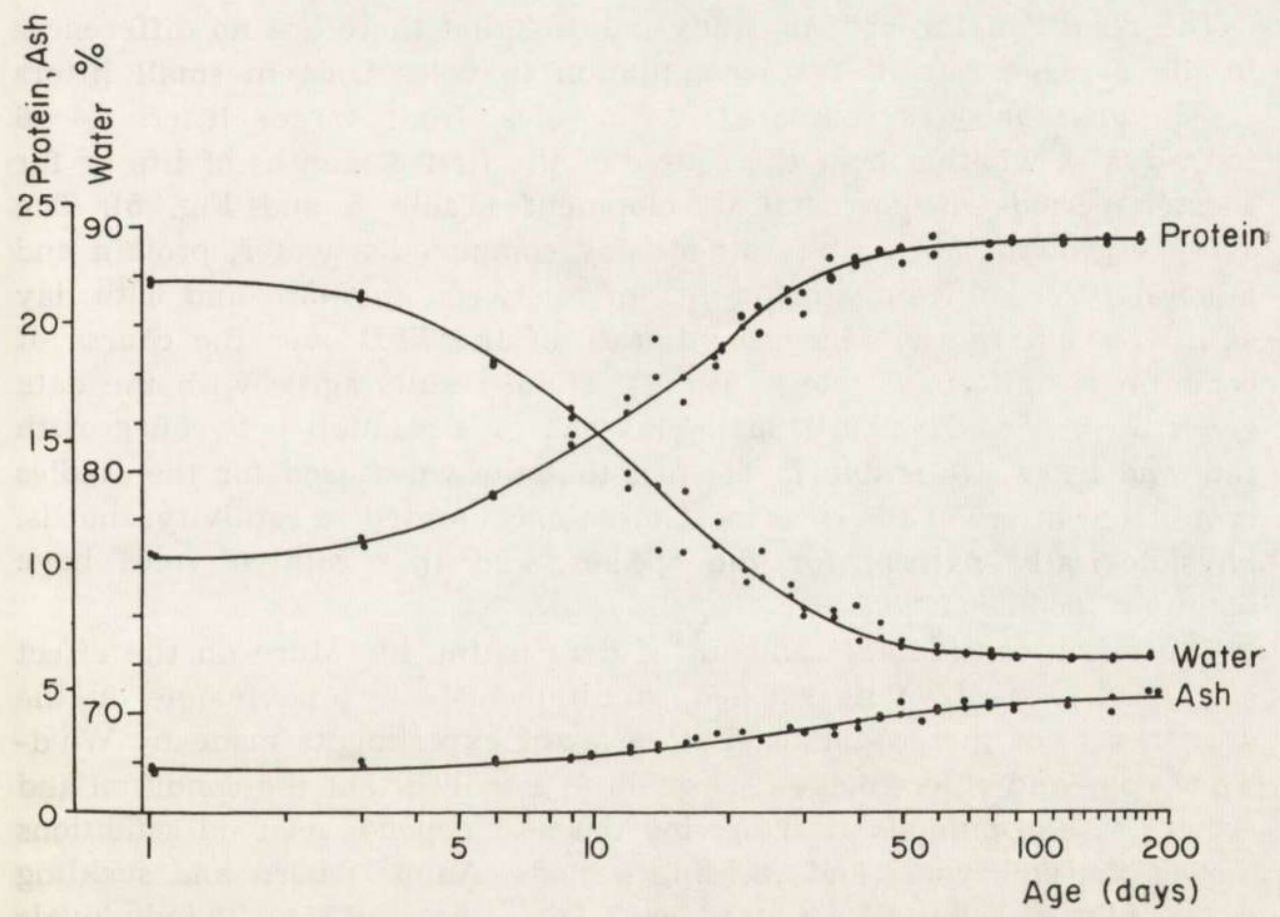

Fig. 6. Changes in proportions of $F F B$ components accompanying the development of laboratory-bred voles. Semi-logarithmic scale.

that the growth rate of $C$. glareolus from small litters ( 3 individuals) is $0.45 \mathrm{~g}$ /day during the first 15 days of life and $0.70 \mathrm{~g}$ /day during the subsequent 10 days. The value of these parameters for voles from larger litters is respectively 0.35 and $0.73 \mathrm{~g} /$ day. Kor abiel $\mathrm{nikov}$ (1972) and Pegel'man \& Kor abielnikov (1972), when comparing large (6-9 voles) and small litters (3-5 voles), also found differences in the weight of the two groups as early as the day of birth. These differences 
increase with age and the difference in the weights of voles from the litters compared on the 40th day of life is as much as $9 \mathrm{~g}$ in favour of individuals born in small litters. The differences in average growth rate for the groups compared during 40 days of their life are thus here greater than the values obtained by Pearson (1962) $(0.34 \mathrm{~g} /$ day for small litters - autor's own calculations). It is not however known if differences between small and large litters, manifested by a more rapid increase in the body mass of individuals from small litters, are caused by the different growth rate of all components, or whether they are due only to a different degree of fat accumulation. We il \& Miller (1971) showed that there are differences in fat accumulation of rats from litters of different size.

The results of the present study indicate that there are no differences in the average rate of fat accumulation in voles born in small litters (1-3 individuals) as compared with voles from larger litters (4-6 individuals), whether over the course of the first 6 months of life or for shorter periods of postnatal development (Table 5 and Fig. 5). The average growth rate for the other body components: water, protein and minerals, is significantly different only between the 45th and 60th day of life - but the average growth rate of the FFB over the course of 6 month is uniform (Table 3, Fig. 1). These results agree with the data given by Sviridenko (1959). The lack of a relation between growth rate and litter size is due to the fact that the voles used for the studies came from litters of the sizes most often encountered in captivity, that is, physiologically natural for the species, and that captive voles have optimum food conditions.

There is a considerable amount of data in the literature on the effect of the number of young suckled simultaneously by one female on the growth rate of these animals. The series of experiments made by $\mathrm{W}$ iddow son and others made it possible to establish that the condition and growth rate of animals after leaving the nest depends on food conditions during the embryonic and suckling periods. Animals born and suckling in large litters, when density was artificially increased (14-21 individuals in rats) grew more slowly and their growth was sometimes even inhibited, in comparison with individuals from small litters (Widdow so $\mathrm{n}$ \& $\mathrm{K}$ ennedy, 1962; McCance, 1962). Under natural conditions starvation of suckling probably does not occur, as reproduction is regulated by different factors such as: limitation of the number of young born by resorption of embryos under unfavourable food conditions, limitation of the number of females participating in reproduction depending on population numbers etc.

In accordance with the definition of the phenomenon of growth it 
was that this is a process of dynamic changes taking place in time. The growth rate of the FFB under the influence of its components is significantly different for each of two optional periods of development (see Table 3, Fig. 2). The rate of fat accumulation differs during the first two periods of development and is also different from that in periods III and IV. These last two periods of development are characterized by an almost identical rate of fat accumulation.

P e a r s o n (1962) distinguished two phases of postnatal growth in $C$. glareolus during the first 25 days of life. The initial phase, covering the period from birth to the time eyes open, is characterized by a slower growth rate of body mass than in the subsequent phase of growth acceleration. The observations were confirmed by $\mathrm{S}$ awicka-Kapusta (1974), who observed the most rapid increase in gross body composition between the 20th and 30th day of life (on an average $0.70 \mathrm{~g} /$ day, with $0.22 \mathrm{~g} /$ day for a period of 70 days of life). The growth acceleration period between the 20 th and 30 th day of life, which also took place in the voles studied here, is characterized by a growth rate of $0.84 \mathrm{~g} /$ day, whereas the average growth rate of $F F B$ during 6 month of life was $0.068 \mathrm{~g} /$ day.

It is possible to distinguish three growth phases during the 6 months period of postnatal development in captive voles:

(1) from the 1st to approx. 20th day of life - average growth rate;

(2) from the 22 nd to 30 th day of life - growth acceleration;

(3) from the 30th to 180 th day of life - a slow increase, almost seven times less than during the first phase, and over thirty times slower than during the first phase, and over thirty times slower than in the second phase.

The average body weight for the voles described above, on the 60th day of life, in comparison with this parameter in 40-day old voles, or the smaller body weight in 150-day old voles in comparison with 120-day old or even 40-day old animals was at first thought to be due to the influence of the season in which the animal was born. There were in fact individuals born in autumn and winter in the group of 60-day old voles (there are no such voles in the group of 40-day old animals), but their weight and in particular the $F F B$ composition in percentages, which

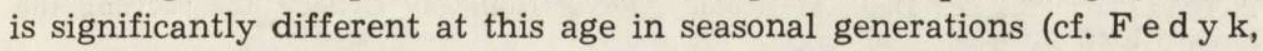
1974 a), did not differ from the same indices for captive animals born in spring. The differences found are due to the variable body weight of individuals even though belonging to one litter, for instance the empty body weights of voles from a litter of 6 specimens varied from 12.8 to $17.9 \mathrm{~g}$ at the age of 60 days. Hence the conclusion that the cause of the lower average body weights in older voles in comparison with younger animals is due to the variability in this parameter undoubtedly connected 
with the formation of hierarchic relationships within the group (cf. Bas henina, 1969/70). The statistical significance of some differences in average body, weights was not reflected in the kinetics of gross body composition, which justified the two groups compared being treated jointly.

It was shown that captive voles attain chemical maturity at the age of 55-60 days, with average water content in the $F F B$ of approx. $72.3 \%$, which agrees with the data obtained for white mice (B a iley et al., 1960).

On the basis of data on the body composition of captive voles originating from the Niepolomice Forest (S a wicka-Kapusta, 1974) it may be said that despite the uniform percentage composition of the $F F B$ in the voles examined on the day of brith, voles from the Niepolomice Forest attain chemical maturity at the same time, but with different protein and water contents in the FFB. Thus the level of gross body composition in the stage of chemical maturity is not a feature characteristic of the species, but applies only to local populations (cf. Widdow so n \& Di ckerson, 1960).

The calorific values of the bodies of mammals provide valuable information in bioenergetic studies. Such studies have been carried aut at random on a few individuals (Golley, 1961; S lo bodkin, 1962; Davis \& Golley, 1963; Myrcha, 1968), but also from seasonal aspect (G ór ecki, 1965; M y r ch a, 1959), and also in postnatal development (M y r c ha \& W a l k ow a, 1967; S a wi cka-Kapusta, 1970; 1974). As the calorific value has been given converted to a unit of biomass weight, this parameter changes depending on the amount of water and fat in the tissues. It has been shown above that the calorific values of a unit by weight of protein and fat is a constant value over a six-month period of the development of C. glareolus, and therefore it is sufficient to known the fat content of the body in adult animals in order to determine its calorific value.

Acknowledgements: I wish to express my thanks to Professor Z. Pu cek, Dr. M. $\mathrm{Gębczyński}$ and $\mathrm{E}$. Malzahn, M. Sc. for many valuable comments during this work and critical reading of the manuscript. Thanks are also due to Mr. T. H e a ling, M. Sc., Dept. of Zoology, Royal Holloway College, for revising the English text.

\section{REFERENCES}

1. B a ile y C. B., Kitts W. D. \& Wood A. J., 1960: Changes in the gross chemical composition of the mouse during growth in relation to the assessement of physiological age. Can. J. Anim. Sci., 40: 143-155.

2. Bashenina N. V., 1969/70: Effect of adaptive charcteristics of seasonal dimorphism on regulation of population density of small rodents. [In: "Energy 
flow through small mammal populations. Eds.: Petrusewicz K. \& R yszk ow s k i L.]. Państw. Wyd. Nauk.: 221-232. Warszawa.

3. B e r g s t e d t B., 1965: Distribution, reproduction, growth and dynamics of the rodent species Clethrionomys glareolus ( $\mathrm{S} \mathrm{chreber,} \mathrm{1780),} \mathrm{Apodemus} \mathrm{flavi-}$ collis ( $\mathrm{Mel} \mathrm{ch}$ ior) and Apodemus sylvaticus ( $\mathrm{L}$ inné) in Southern Sweden. Oikos, 16: 132-160.

4. Bujalska G. \& Gliwicz J., 1968: Productivity investigation of an island population of Clethrionomys glareolus ( $\mathrm{S} \mathrm{chreber}, 1780$ ). III. Individual growth curve. Acta theriol., 13: 427-432.

5. Cla u d e C., 1970: Biometric und Fortpflanzugsbiologie der Rötelmaus Clethrionomys glareolus (S c h r e b e r, 1780) auf verschiedenen Höhenstufen der Schweiz. Rev. suisse Zool., 77: 435-480.

6. Craw ley M. C., 1970: Some population dynamics of bank vole, Clethrionomys glareolus, and wood mouse, Apodemus sylvaticus in mixed woodland. J. Zool., 160: $1-89$.

7. Davis D. E. \& Golle y F. B., 1963: Principles in mammalogy. Reinhold Publ. Corp.: 1-335. New York.

8. Drożdż A., 1965: Wplyw paszy na dojrzewanie płciowe samców nornicy rudej (Clethrionomys glareolus Schr.). Zwierz. lab., 3: 34-45.

9. Em a li a n o v S. V., 1966: The tempo of individual development of animals and its role in the evolution. Anat. Anz., 118: 415-422.

10. Ela n d t R., 1958: Statystyczne badanie prawidłowości zjawisk w czasie i przestrzeni. Roczn. Nauk roln., 79, A: $401-424$.

11. Fedy k A., 1974 a: Gross body composition in the postnatal development of bank vole. II. Differentiation of seasonal generations. Acta theriol., 19: 403-427.

12. F edyk A., 1974 b: Gross body composition in the postnatal development of the bank vole. III. Estimating age. Acta theriol., 19: 429-440.

13. Fedyk A. \& Malzahn E., 1975: Determination the protein value in small mammals. Acta theriol., 20.

14. Golle y F .B., 1961: Energy values of ecological materials. Ecology, 42: 581-584 .

15. Górecki A., 1965: Energy values of body in small mammals. Acta theriol., 10: $333-352$.

16. Kaikusalo A., 1972: Population turnover and wintering of the bank vole, Clethrionomys glareolus (S $\mathrm{ch} \mathrm{reb}$ ), in Southern and Central Finland. Ann. Zool. Fennici, 9: 219-224.

17. Korabelnikov V. M., 1972: Zavisimost' rosta i postembrionalnogo razvitija evropejskoj ryžej polevki (C. glareolus $\mathrm{S} \mathrm{chreb}$.) ot veličiny vyvodka. Zool. Ž., 51: $464-466$.

18. Krauze S., B ożyk Z. \& Piekarski L., 1966: Podręcznik laboratoryjny analityka żywnościowego. Państw. Zakł. Wyd. Lek.: 1-588. Warszawa.

19. Ku bik J., 1965: Biomorphological variability of the population of Clethrionomys glareolus. Acta theriol., 10: 117-179.

20. Mazák V., 1962: Zur Kenntnis der postnatalen Entwicklung der Rötelmaus, Clethrionomys glareolus S chreber, 1780 (Mammalia, Microtidae). Věst. Cs. spol. zool., 26: 77-104.

21. McCance R. A., 1962: Food, growth and time. Lancet, 2: 671-675.

22. Morrison P. R., Ryser F. A. \& Strecker R. L., 1954: Growth and development of temperature regulation in the tundra redback vole. J. Mammal., 35: $376-386$. 
23. Moulton C. R., 1923: Age and chemical development in mammals. J. biol. Chem., 57: 79-97.

24. My r cha A., 1968: Caloric value and chemical composition of the body of the European hare. Acta theriol., 13: 65-71.

25. My r cha A., 1969: Seasonal changes in caloric value, body water and fat in some shrews. Acta theriol., 14: 211-227.

26. Myrcha A. \& Walkowa W., 1968: Changes in the caloric value of the body during the postnatal development of white mice. Acta theriol., 13: 391-400 .

27. N e w S on R. 1963: Differences in numbers, reproduction and survival between two neighboring populations of bank voles (Clethrionomys glarealus). Ecology, 44: $110-120$.

28. P e a rs on A. M., 1962: Activity patterns, energy metabolism and growth rate of the voles C. glareolus in Finland. Ann. Zool. Soc. „Vanamo”, 24: 1-58.

29. Pegel'man S. G. \& Korabelnikov V. M., 1972: Veličina vyvodkov i temp razvitija potomstva u gryzunov. Ekologija, 2: $36-43$.

30. P e trov O. V. \& A ir a pet'jans A. E., 1961: O rozmnoženii i pervyh stadijah posteombrionalnoge razvitija ryžej polevki $\mathrm{v}$ laboratornyh uslovijah. Vest. Leningr. Univ., 21: $51-61$.

31. Sawicka-Kapusta K., 1970: Changes in the gross body composition and caloric value of the common voles during their postnatal development. Acta theriol., 15: 67-79.

32. Sawicka-Kapusta K., 1974: Changes in the gross body composition and energy value of the bank vole during their postnatal development. Acta theriol. 19, 3: $27-54$.

33. Slobodkin L. B., 1962: Energy in animal ecology. [In: "Advances in ecological research", ed. Cragg J. B.]. Academic Press, 1: 69-101. London - New York.

34. Svirydenko P. A., 1959: Rost i razvitije evropejskoj ryžej polevki (Clethrionomys glareolus S c h r e b.) Zool. Ž., 38: 756-766.

35. W e il W. B. Jr. \& M i 11 e r I., 1971: The role of whole carcass analysis in understanding body composition. Pediatrics, 47: 275-288.

36. Widdows on E. M. \& Dickers on J. W. T., 1960: The effect of growth and function on the chemical composition of soft tissues. Biochem. J., 77: 30$-43$.

37. W id dow s on E. M. \& K ennedy G. C., 1962: Rate of growth, mature weight and life-span. Proc. Roy. Soc. (Lond), B, 156: 96-108.

38. $\mathrm{Zejda}$ J., 1971: Differential growth of three cohorts of the bank vole, Clethrionomys glareolus S chreb., 1780. Zool. listy, 20: 229-245.

Accepted, May 30, 1974.

Mammals Research Institute, Polish Academy of Sciences, 17-230 Białowieża, Poland 


\section{Anna FEDYK}

\section{PODSTAWOWE SKEADNIKI CIAŁA W ROZWOJU POSTNATALNYM NORNICY RUDEJ.}

\section{WZROST W WARUNKACH HODOWLI}

\section{Streszczenie}

Zbadano podstawowe składniki ciała: tłuszcz, białko, wodę i substancje mineralne podczas pierwszych 6 miesięcy życia nornic (Clethrionomys glareolus), ulaboratoryjnianych w ciągu 8-12 pokoleń. Uzyskane wyniki opracowano statystycznie, opisując relacje między otłuszczeniem a ciężarem ciała równaniami regresji prostej, natomiast tempo przyrostu beztłuszczowej masy ciała $(F F B)$ w zależności od przyrostu jej komponentów - równaniami regresji wielokrotnej. Powyższymi równaniami opisano przeciętne dla 6 miesięcy rozwoju tempo przyrostu tłuszczu i komponentów FFB jak też tempo przyrostu tych substancji w poszczególnych etapach rozwoju. Oddzielnej analizie poddano dane uzyskane od nornic urodzonych i wychowanych w miotach małych ( $1-3$ osob.) i nornic pochodzących z miotów dużych (4-6 osob.).

Mimo istotnych różnic w ciężarze ciała i jego składnkiów, jakie stwierdzono u nornic wychowanych w miotach małych, w porównaniu z odnośnymi danymi pochodzącymi od zwierząt $\mathrm{z}$ miotów dużych, brak jest różnic $\mathrm{w}$ tempie otłuszczenia obydwu porównywanych grup nornic (Tabela 5, Fig. 5 a również Tabele 2 i 4). Przeciętne tempo przyrostu pozostałych składników ciała: wody, białka i substancji mineralnych jest $u$ nich różne jedynie między 45 a 60 dniem życia. Natomiast przeciętre dla 6 miesięcy życia tempo przyrostu FFB nie zależy od wielkości miotu, w którym się zwierzę urodziło i wychowało (Fig. 1 i 2, Tabela 3).

Niezależnie od sezonu urodzenia, nornice ulaboratoryjniane uzyskują dojrzałość chemiczną w wieku $55-60$ dni (Fig. 6). 